\title{
Next Generation Delivery System for Proteins and Genes of Therapeutic Purpose: Why and How?
}

\author{
Ashish Ranjan Sharma, ${ }^{1}$ Shyamal Kumar Kundu, ${ }^{2}$ Ju-Suk Nam, ${ }^{1}$ Garima Sharma, \\ C. George Priya Doss, ${ }^{3}$ Sang-Soo Lee, ${ }^{1}$ and Chiranjib Chakraborty ${ }^{1,4}$ \\ ${ }^{1}$ Institute for Skeletal Aging \& Orthopedic Surgery, Hallym University Chuncheon Sacred Heart Hospital, \\ Chuncheon 200704, Republic of Korea \\ ${ }^{2}$ Department of Physics, School of Basic and Applied Sciences, Galgotias University, Greater Noida 203201, India \\ ${ }^{3}$ Medical Biotechnology Division, School of Biosciences and Technology, VIT University, Vellore, Tamil Nadu 632014, India \\ ${ }^{4}$ Department of Bioinformatics, School of Computer Sciences, Galgotias University, Greater Noida 203201, India
}

Correspondence should be addressed to Sang-Soo Lee; totalhip@hallym.ac.kr and Chiranjib Chakraborty; drchiranjib@yahoo.com

Received 28 February 2014; Accepted 9 April 2014; Published 15 July 2014

Academic Editor: Surendra Nimesh

Copyright (C) 2014 Ashish Ranjan Sharma et al. This is an open access article distributed under the Creative Commons Attribution License, which permits unrestricted use, distribution, and reproduction in any medium, provided the original work is properly cited.

Proteins and genes of therapeutic interests in conjunction with different delivery systems are growing towards new heights. "Next generation delivery systems" may provide more efficient platform for delivery of proteins and genes. In the present review, snapshots about the benefits of proteins or gene therapy, general procedures for therapeutic protein or gene delivery system, and different next generation delivery system such as liposome, PEGylation, HESylation, and nanoparticle based delivery have been depicted with their detailed explanation.

\section{Introduction}

Over the last few years, numerous therapeutic proteins and peptides have been approved for clinical usage. Till date, more than 135 different therapeutic proteins and genes have been approved by US-FDA for clinical use, and various therapeutic proteins are in the process of development $[1$, 2]. It was a landmark discovery in the medical science when insulin was purified from bovine and porcine pancreas and was utilized as a life-saving injection for patients with type I diabetes mellitus (T1DM) in 1922 [3]. At that time, some issues were associated with this insulin treatment such as availability of animal pancreases especially bovine and porcine pancreases, immunogenicity of animal insulin to some patients, and cost of the protein [4]. It was noted that about $5 \%$ of all patients were having insulin allergy [5]. The problem was solved through recombinant DNA technology, which helped in the production of recombinant insulin using E. coli expression system [6, 7]. Insulin was the first commercially available recombinant therapeutic protein, approved by the US-FDA in 1982, and presently is the most significant treatment for T1DM $[8,9]$. Presently, with the help of biotechnology and recombinant DNA technology, several recombinant therapeutic proteins are being developed and marketed as biopharmaceutical, and the sales value of these recombinant proteins has gained the highest level of market share in pharmaceutical sector [10, 11].

With the beginning of recombinant DNA technology, the idea was to use nucleic acids to cure diseased cells, especially in cells where gene is deleted or mutated. For this mode of therapeutic application, in 1972, Friedmann and Roblin gave the term "gene therapy" [12]. After this report, there have been many debates on pros and cons of gene therapy technology [13]. However, slowly, due to novel advantages of gene therapy, it is entering into the mainstream of treatment. More than 1800 gene therapy clinical trials have been completed throughout the world and many are continuing [14]. Therefore, developing efficient gene delivery technology is one of the significant areas for pharmaceutical industry in current era [15]. 
Presently, pharmaceutical delivery system (PDS) or drug delivery system (DDT) is very important for the pharmaceutical industry. Many pharmacological properties of traditional molecules can be improved with the help of DDS $[16,17]$. The effectiveness and marketability of the drug molecules depend on the mode of DDS. Pharmaceutical industries are prone to generate new DDS which can impart novel properties to existing as well as newly discovered products. New DDS will be more efficient and safer compared to the existing one [18]. Presently, many existing drug molecule/marketed drugs use new delivery systems and are of great interest for doctors or medical professionals $[19,20]$. It has been noted that market value, competitiveness, and patent life may boost up for an existing drug candidate molecule if we use a new DDS. Therefore, the existing drug candidate molecules may offer a new opportunity to increase the market price and competitiveness in the pharmaceutical market [21]. Conversely, patent expiry is one of the major alarms for the pharmaceutical industry. A new DDS can provide a new marketability to an existing drug molecule. Therefore, the development of novel delivery systems is at high priority for the pharmaceutical companies to capture global market. Pharmaceutical market is projected to have a growth with compound annual growth rate of approximately 5\% [22]. Biopharmaceuticals (especially therapeutic proteins and gene therapy) are one of the fastest growing areas of the pharmaceutical business. The first generation therapeutic protein based drugs are currently passing through a number of difficulties and needs for improvement. The therapeutic protein delivery system (TPDS) offers longer circulation time for the therapeutic protein in the patient's body and enhanced pharmacokinetics (PK) and pharmacodynamics (PD) properties and is now extremely valuable from the commercial point of view [23]. One the other hand, the efficient gene delivery system can improve the means for delivering genes during gene therapy and thus can contribute toward more successful clinical outcomes [24].

In this paper, we have tried to highlight next generation delivery systems and benefits of proteins therapy or gene therapy. Efforts have been made to summarize general procedures for therapeutic protein or gene delivery system and different next generation delivery systems, namely, liposome, PEGylation, HESylation, and nanoparticle based delivery along with their detailed description.

\section{Why Proteins Therapy or Gene Therapy?}

Over the last few years, biopharmaceuticals especially therapeutic proteins have received great attention. As per the research and markets report by "Global Protein Therapeutics Market Forecast to 2015," the global market for biopharmaceuticals is growing and is likely to reach the target of $\$ 143.4$ by 2016 . Among the biopharmaceuticals, therapeutic proteins and genes delivery have gained the maximum percentage of market share [25].

It has been found that protein therapeutics has some advantages over small-molecule drug molecules, which may be summarized as follows. (i) Therapeutic proteins can provide efficient replacement treatment when gene is deleted or mutated. This treatment can help us without any gene therapy. (ii) Proteins perform very scrupulous and multifarious functions which are explicit and exclusive. It is very difficult to imitate this distinctive possessed function of enzymes by simple chemicals. (iii) It has been noted that the effect of proteins is extremely specific. So, there is very little chance for the hindrance of normal biological processes with the therapeutic proteins that cause unsympathetic effect. (iv) Biologically, our body creates many kinds of proteins which can be used as therapeutics. Since these proteins are produced from our body itself, they are well tolerated. Therefore, the chance of failure is fewer during the clinical trials. (v) The regulatory approval time of therapeutic proteins is faster than that of small-molecule drugs. The regulatory authority in USA, US-FDA, approves a therapeutic protein compared to small-molecule drugs in the short span of time. From financial point of view, these benefits make therapeutic protein attractive to the pharmaceutical industry $[1,26]$.

Gene therapy may provide novel treatments for diseases having no effective conventional treatment. Gene therapy can be the ultimate solution for genetic disorders, as it can help to replace deleted or mutated gene for correcting genetic disorders. This possibility of amending genetic disorder is gaining importance and researches are trying to deliver genes to the affected cells. Major factor affecting efficacy for gene therapy is gene delivery system. The refinements to the delivery system may increase security as well as the long-term expression of the gene of interest and reduce the chance of mutagenesis of the particular gene. After gene replacement therapy, the patient needs not receive the treatment of protein based therapeutics regularly, making it one of the desired lines of treatment $[27,28]$.

\section{General Strategies for Therapeutic Protein or Gene Delivery System}

Other than the above benefits, some limitations have been noted of therapeutic proteins and genes. The main disadvantage is the stability associated with these proteins or genes which is often not proper. The half-life is also limited. Immunogenicity is another problem for therapeutic protein or genes. For the therapeutic proteins, it has also been observed that light sensitivity, moisture, temperature, and so forth, hamper their stability. Many strategies have been undertaken to improve these limitations. Among them, two strategies are frequently being employed: one is the change in the therapeutic protein (development through the alteration in protein configuration or covalent add-on) itself and through development in the formulation [29, 30]. Proteins are generally conjugated with natural or synthetic polymers (PEGylation, HESylation, and polysialylation) to alter structure of therapeutic proteins [31, 32]. Conversely, different drug formulation systems are also being used to overcome the existing limitations of therapeutic proteins. These formulation systems are polymeric microspheres, polymeric nanoparticles, liposomes, and so forth [33].

For gene delivery, viral vectors and nonviral vectors are usually used. Major viral based gene delivery systems 


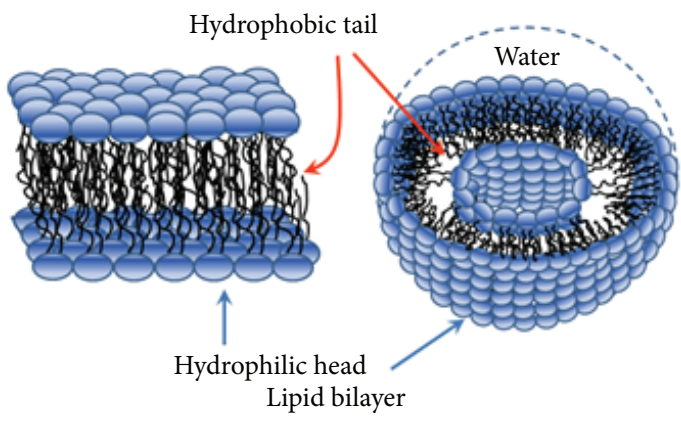

FIGURE 1: Diagrammatic representation of lipid bilayer used for encapsulating therapeutic proteins and genes for their delivery.

are adeno-associated viral vectors [34]; retroviral/lentiviral vectors [35] and nonviral based delivery systems are cationic liposome [36] and PEGylated system [37].

\subsection{Liposome for Therapeutic Protein or Gene Delivery System.} The efficiency of a number of drugs is often limited by their potential to reach the site of therapeutic effect. In most cases, only a small amount of a controlled dose reaches the target site, while the majority of the drug allocates throughout the rest of the body in accordance with its physic-chemical and biochemical properties. Therefore, it is very challenging task to enhance the pharmaceutical effect of drugs while reducing its toxicity in vivo. These objectives can only be achieved through next generation delivery system. Lipid molecules of biomembranes interacting with water molecules can control the transport phenomena and protein functions with anisotropic flow experience. After the discovery in 1965, liposomes were used for delivery of peptide and protein drugs [38-41]. For the development of liposome-based drug delivery system, a consistent size distribution is necessary to produce the nanocarrier's in vitro features (e.g., drug loading capacity, aggregation, sedimentation, etc. $[42,43])$. Considerable attention has been paid for liposomal drug delivery systems due to their specific attributes, such as (i) successful encapsulation of molecules where both tiny and large molecules are present and the molecules are having a wide range of hydrophobic levels and pKa values; (ii) prolonging and target release of therapeutic agents by modification of liposome surface; and (iii) minimization of clinical drug dose and reducing toxicity results $[44,45]$.

A number of experimental reports have been successfully published on the medical use of liposomes, consisting of the lipid bilayer membrane, as a drug carrier for the purpose of the reduction of drug toxicity or targeting of drugs to specific cells [46-49] (Figure 1). Clearly, it is not probable to deal with all relevant issues, so emphasis will be made to address some key topics, including successes and main challenge and limits of liposomes in protein and peptide delivery.

3.2. Liposome Preparation. The main objective for the use of liposome as drug carriers is to target specific tissues such as tumours and also to reduce toxic side effects in sensitive organs such as liver, heart, and kidneys. Additionally, it is possible to extend the therapeutic index of liposomal carriers over that of the corresponding conventional formulations by optimizing the lipid composition, liposomal size, membrane fluidity, surface charge, steric stabilization, and so forth.

The amphiphilic molecules used for liposomal preparations are based on the structure of biological membranes lipids [57-63]. For liposome synthesis two hydrocarbon chains are usually esterified to a glycerol backbone. These hydrophobic chains are further connected to a hydrophilic head group containing either a phosphate or some carbohydrate units. These lipid head groups are either zwitterionic (phosphatidylcholine, phosphatidylethanolamine, sphingomyelin), negatively charged lipids (phosphatidic acid, phosphatidyl glycerol, phosphatidyl serine, phosphatidyl inositol, cardiolipin, substituted glycolipids such as monosialoganglioside), or entirely uncharged lipids (unsubstituted glycolipids). Examples of cationic amphiphiles are DOTAP, DODAC, DC-Chol, DMRIE, DOTMA, DOSPA, DOGS, and many others.

Amphiphilic lipid monomers are weakly soluble in water having low critical micelle concentration (CMC), depending on the hydrocarbon chain length. These single-chain lipids (lysolipids, free unsaturated acyl chains, detergents, etc.) spontaneously assemble into micelles which further act as membrane lipids and tend to form bilayers. Figure 1 illustrates the bilayer structures which form closed vesicles, that is, liposomes. One can distinguish between multilamellar and unilamellar vesicles which can be varied from minute vesicles (size, $<100 \mathrm{~nm}$ ), large vesicles (size, 100-500 nm), or huge vesicles (size, $\geq 1 \mu \mathrm{m}$ ). Some isolated lipids or lipid mixtures may prefer nonbilayer morphologies such as hexagonal and cubic phases.

Therapeutic genes and proteins can be (i) encapsulated within the liposome and (ii) chemically conjugated to the surface groups. With the help of liposome, passive encapsulation can be achieved by incubating genes, protein, or peptide at or somewhat lower than the phase transition temperature, used for the preparation of liposome. Vigorous loading of therapeutic genes and proteins, termed as triggered loading, can also be achieved by increasing temperature in presence of ethanolic buffer and mild swirling for a particular period. This simple process is somewhat fast and is used to attain higher encapsulation efficiency [64]. Usually proteins are required to exist in aqueous core position. On the other hand, uncovered hydrophobic regions of protein may work together with the lipid membrane. However, the interaction between proteins and lipids are normally to maintain the bioactivity of proteins [65].

Initially, conjugation of proteins with the liposomes was explored by means of glutaraldehyde or 1-ethyl-3(3-dimethylaminopropyl) carbodiimide (EDC); afterwards researchers are also working on selective bi-functional coupling agents $[66,67]$. These reactions encouraged the development of liposome into additional advanced forms and include (i) immunoliposomes, conjugated to antibodies or antibody fragments $[68,69]$, (ii) stealth liposomes connected with PEG, provides protective coat for evading recognition by opsonins and slowing down clearance [70-72], (iii) extended flowing immunoliposomes coated together with protecting 
polymer and also with antibodies [71, 73], and (iv) the next generation of liposomes which permit alteration to the exterior surface through a number of compounds that are either alone or in concert including stimuli sensitive lipids, polymers, cell penetrating peptides, and diagnostic agents $[72,73]$.

For the treatment of liver tumours or metastases, investigators are continuing to use galactosylated liposome for targeted delivery of drugs to liver [74]. The capability of these galactosylated liposomes led to their use in gene delivery systems to deliver in targeted cells [75]. The presence of lipid that is able to form nonbilayer structures, such as dioleoylphosphatidyl ethanolamine (DOPE), can endorse destabilization of the bilayer, inducing fusion events. DOPE has been particularly beneficial for cationic liposomes complex formation with plasmid DNA for gene delivery [76, 77].

\subsection{Liposomes Acting as Carriers of Protein and Gene Therapy.} Biologically active complexes of genes and proteins, for example, small interfering RNA (siRNA), cytokines, enzymes, peptide hormones, and others, are the choice of drugs which could be very useful for the treatment of various diseases. The incorporation of these therapeutic moieties/drugs in liposomal membranes offers several advantages such as high drug incorporation efficiency; stable confinement of drugs in the liposome; prevention of drugs against metabolic degeneration; and long-term therapeutic stage. The supportive effects provided by liposomes have been employed to a wide range of proteins and genes. Superoxide dismutase (SOD), a cytotoxic agent used during phagocytosis, is an enzyme which protects from the effects of superoxide anion. Liposomal encapsulation of SOD has been found to increase its performance, extend circulation, and reduced membrane peroxidation in different areas of brain [78, 79]. Spraydried powder formulations of the active SOD in liposomes mixed with disaccharides have also been described [80]. The potential ability of liposome-encapsulated enzymes to enter the cytoplasm or lysosomes of live cells is of crucial importance for the treatment of congenital diseases produced by the abnormal behaviour of some intracellular enzymes [81]. Gaspar et al. reported that survival of animals with asparagine dependent tumours associated with free enzymes is increased by the application of liposome-encapsulated asparaginase [82]. In addition, such liposomal encapsulated asparaginase also avoids the formation of anti-asparaginase antibodies. In another study, enhanced thrombolytic activity was observed by tissue plasminogen activator encapsulated in liposomes, as compared to native enzyme, when employed for thrombolytic treatment in rabbits with jugular vein thrombosis [83]. An interesting approach applying liposome liposomes encapsulated enzymes is antibody-directed enzyme prodrug therapy (ADEPT), based on the on-site activation of chemically modified inactive anticancer and antiviral prodrugs into active therapeutic agents [84]. To achieve the specific production of active cytotoxic molecules from inactive drugs in the areas of tumour cells, a conjugate drug was developed using tumour-specific antibody along with an enzyme responsible for the conversion of inactive drug into the active form. For enhancing the enzymatic activity of obligatory enzyme in tumour cells, moderately than just "straight" antibody-enzyme conjugates, a unique liposome, namely, immunoliposomes, is loaded with the essential enzyme [85].

In spite of intensive efforts intended for designing a number of different cationic lipids [86-88], gene expression can only be detected after local administration instead of systemic injection, along with the evident toxic side effects of cationic lipids $[89,90]$. Cationic lipid-DNA complexes face supplementary issues due to their large size and high surface charge combining together to result in fast elimination from the circulation. However, large numbers of theories are emerging from huge and quickly rising literature in the arena of delivering nucleic acids which are (i) positively charged cationic lipids, which is considered necessary for the effective relationship of nucleic acids with lipids [91], (ii) liposomes with positive charge results in their fast clearance by the mononuclear phagocyte system (MPS) and not specific cell binding [92], (iii) the circulatory half-life of liposome mediated delivery of nucleic acids that can be increased by modifying surface charge to near neutrality either by coating the cationic liposomes (CCLs) [93] or by using of ionizable lipids [94-97], (iv) for particular binding and internalization, the targeted ligands being mandatory [98, 99], and (v) efficient endosomal release following internalization being needed for therapeutic activity [100], which can be provided by ionizable cationic lipids with optimized bilayer destabilizing capacities and $\mathrm{pKa}[97,101]$.

\section{PEGylation Carriers of Therapeutic Proteins and Genes}

PEGylation is a process through which polyethylene glycol (PEG) chains are conjugated to proteins (therapeutic proteins), peptides, or any molecules. In 1990, US-FDA approved the first PEGylated therapeutic protein and its brand name is Adagen (pegadamase), marketed by a USA pharma company (Enzon Pharmaceuticals) for the cure of Severe Combined Immunodeficiency Disease (SCID) [102]. After that, USFDA approved about seven therapeutic proteins [103]. Till date, several therapeutics (approximately 80 polypeptide medicines) are marketed in USA and approximately 350 are undergoing clinical trials. Among them, many are PEGylated therapeutic protein [104]. Through the PEGylation process, the molecular mass of therapeutic proteins is increased. Therefore, it guards the therapeutic protein from the proteolytic enzymes and thereby degradation of the proteins. It has been noted that PEGylation process improves pharmacokinetics of the therapeutic protein.

4.1. Procedure of PEGylation. PEG is hydrophilic, safe, nonimmunogenic polymers. These polymers are chemically inert repetitive units of ethylene oxide. In the toxic point of view, this molecule is generally accepted as safer molecule [103]. PEG reagents are commercially available as linear or branched configurations with different lengths, shapes, and chemistries and molecular weights. It is commercially available from some companies from Asia, particularly such 


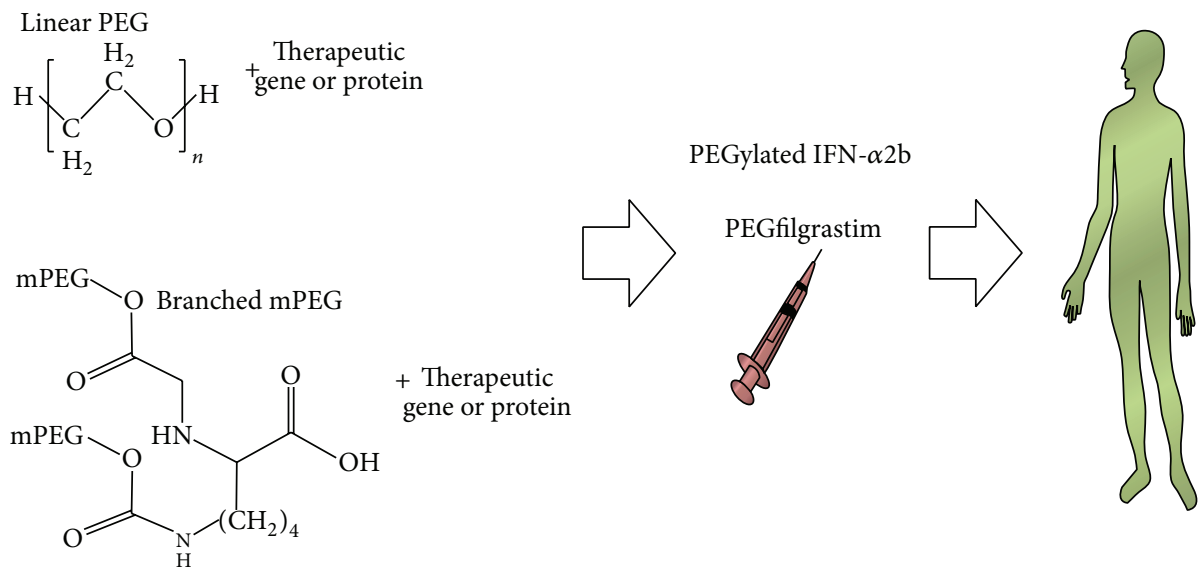

FIGURE 2: Schematic diagram representing systemic delivery of therapeutic proteins or genes following conjugation with polyethylene glycol molecules. Here, structural formulae for linear PEG and branched $\mathrm{mPEG}$ are also displayed.

as NOF corporation (Japan); SunBio (South Korea); Reddy's Lab (India), and JenKem (China). Some other important companies are Chirotech Technology Limited (UK), Creative PEGWorks (USA), and so forth [104].

It is compulsory to activate the PEG moiety to conjugate it with therapeutic proteins. For the reaction with PEG moiety, different chemical groups in the amino acid of therapeutic protein side chains such as $\mathrm{NH} 2,-\mathrm{NH}-,-\mathrm{COOH},-\mathrm{OH}$, -SH groups and disulfide (-S-S-) bonds can be exploited. Therefore, in this process, reaction occurs between the amino acid of therapeutic protein and suitably activated PEGylation reagents. It has been shown that the reactive amino acids that often participate during this conjugation process are arginine, aspartic acid, histidine, lysine, cysteine, glutamic acid, threonine, tyrosine, and serine. Other than that, $\mathrm{N}$ terminal amino group and the $\mathrm{C}$-terminal carboxylic acid are also found to be involved with these reactions [105].

Several PEGylated therapeutic proteins have been reported till date, which includes Peginterferon $\alpha 2 b$ (PegIntron), PEGylation of IFN- $\alpha 2 \mathrm{a}$ as a preliminary therapy for the chronic hepatitis C [106, 107], and mono-PEGylated TNF- $\alpha$ for antitumor treatment [108] (Figure 2).

Some PEGylated gene therapy has also been performed. Adenosine deaminase-deficiency (ADA-SCID) is a kind of immunodeficiency. ADA is involved in the purine salvage pathway and absence of this enzyme leads to build-up of intracellular and extracellular substrates (adenosine or deoxyadenosine) leading to adverse effects on the functions of different cell types. In case of immune cells it leads to severe lymphopenia with abnormal development of $\mathrm{T}, \mathrm{B}$, and natural killer (NK) cells. In order to cure this immune disorder, PEGylated adenosine deaminase gene has been transferred to T lymphocytes $[109,110]$. Gene therapy for ADA-SCID shows great promise in the treatment of this disease. Using this delivery system, approximately 30 patients with ADA-SCID have been treated worldwide [111, 112]. It has been reported that immune function has been regained without the support of enzyme replacement therapy [113]. Moreover, there were no adverse events reported related to the PEG gene transfer technology $[114,115]$.

4.2. Advantage of PEGylation Procedure. This process augments the solubility of therapeutic proteins. It provides solubility to different solvents such as water and various organic solvents. It has been witnessed that the PEGylated therapeutic protein enhances property for site specific performance. It has also been found to enhance PD, PK properties of the protein. Conversely, this procedure diminishes immunogenicity [116].

\section{HESylation}

HESylation utilizes a hydroxyethyl starch derivative for conjugation to proteins (therapeutic proteins) or drug molecules to increase its size. HESylation name has been derived from "HES" which corresponds to a part of hydroxyethyl starch derivative. HES are natural polymers present in starch along with amylopectin fibers. HES are produced from natural maize starch. Therefore, they are highly biocompatible and biodegradable and are clinically approved as plasma volume expanders (PVEs). These attributes make it an attractive hydrophilic polymer for half-life extension (HLE) technologies $[117,118]$. HESylation delivery system provides extended circulation half-life to the therapeutic molecules. It has been observed that it increases the stability of therapeutic protein and amplifies biological activity. A European pharma company (Fresenius Kabi, www.fresenius-kabi.com) is regularly applying HESylation delivery system to a variety of proteins (e.g., Erythropoietin (EPO) and Granulocyte-colony stimulating factor (G-CSH)) $[26,119]$.

\section{Nanoparticle Based Delivery}

Nanoparticle based delivery of therapeutic proteins and genes is believed to the significant area of drug delivery (Figure 3). For delivery of therapeutic protein or drug, a number of protein-nanoparticle based deliver systems are being used 
TABLE 1: Next generation therapeutic proteins or genes and their delivery system which are in the market or in clinical trial.

\begin{tabular}{|c|c|c|c|c|}
\hline $\begin{array}{l}\text { Brand name of } \\
\text { therapeutic protein/gene }\end{array}$ & Therapeutic protein/gene & Indication & Remark & References \\
\hline Oncaspar & $\begin{array}{l}\text { Therapeutic protein } \\
\text { (pegylated formulation of L-asparaginase; } \\
\text { Pegaspargase) }\end{array}$ & Leukaemia & $\begin{array}{l}\text { USFDA-approved in } \\
1994\end{array}$ & {$[50]$} \\
\hline PEG-INTRON & $\begin{array}{l}\text { Therapeutic protein } \\
\text { (pegylated formulation of IFN-a2B; } \\
\text { Peginterferon alfa-2b) }\end{array}$ & $\begin{array}{l}\text { Hepatitis } \mathrm{C} \text { as well as } \\
\text { malignancies }\end{array}$ & $\begin{array}{l}\text { USFDA-approved in } \\
\text { January } 2000\end{array}$ & {$[51]$} \\
\hline PEGASYS & $\begin{array}{l}\text { Therapeutic protein } \\
\text { (pegylated formulation of IFN-a2A; } \\
\text { Peginterferon alfa-2A) }\end{array}$ & Hepatitis C & $\begin{array}{l}\text { USFDA-approved in } \\
\text { January } 2001\end{array}$ & {$[52]$} \\
\hline Neulasta & $\begin{array}{l}\text { Therapeutic protein } \\
\text { (pegylated formulation of } \\
\text { Granulocyte-colony } \\
\text { stimulating factor (GCSF) and } \\
\text { monomethoxypolyethylene glycol; } \\
\text { Pegfilgrastim) }\end{array}$ & Neutropenia & $\begin{array}{l}\text { USFDA-approved in } \\
\text { January } 2002\end{array}$ & {$[53]$} \\
\hline Mircera & $\begin{array}{l}\text { Therapeutic protein } \\
\text { (pegylated formulation of Erythropoietin } \\
\text { (EPO); Epoetin beta-methoxy } \\
\text { polyethylene glycol) }\end{array}$ & $\begin{array}{l}\text { Anemia associated with } \\
\text { kidney disease }\end{array}$ & $\begin{array}{l}\text { USFDA-approved in } \\
\text { January } 2007\end{array}$ & {$[54]$} \\
\hline $\begin{array}{l}\text { - } \\
\text { (No brand name } \\
\text { available) }\end{array}$ & $\begin{array}{l}\text { Therapeutic gene } \\
\text { (RNAi therapeutics delivery of } \\
\text { ALN-PCS02 using SNALP liposome) }\end{array}$ & Hypercholesterolemia & Clinical trial & {$[55]$} \\
\hline Glybera & $\begin{array}{l}\text { Therapeutic gene } \\
\text { (alipogene tiparvovec used } \\
\text { adeno-associated virus serotype } 1 \text { (AAV1) } \\
\text { viral vector delivery) }\end{array}$ & $\begin{array}{l}\text { Familial lipoprotein lipase } \\
\text { deficiency (LPLD, synonym: } \\
\text { type I hyperlipidaemia). }\end{array}$ & $\begin{array}{l}\text { First gene-therapy } \\
\text { medicine and } \\
\text { approved by all } 27 \\
\text { European Union } \\
\text { member states }\end{array}$ & {$[56]$} \\
\hline
\end{tabular}

such as albumin [120], gelatin [121], and legumin [122]. Conversely, many natural polymers and their derivatives like chitosan, dextran, and starch nanoparticles have also been tried to deliver different proteins and genes.

It has been recently documented that dendrimers [123] biodegradable polymeric nanoparticles [124] and gold nanoparticles [125] have been used for gene therapy. Researchers are usually exploiting two techniques for nucleic acids delivery, that is, encapsulation or conjugation. For nucleic acids like plasmid DNA, RNA, and siRNA, encapsulation methods are usually preferred to deliver nucleic acids with nanoparticles [126]. However, sometimes these nucleic acids are also being conjugated with the nanoparticle for delivery [127-130]. One of the methods to link nucleic acids to a nanoparticle is to modify the surface of the nanoparticle and to provide a positive charge. Positive charge on nanoparticle would favour easy binding of negatively charged DNA. However, this method is used for liposome and other polymermediated gene transfer [131]. Recently, some researchers have generated polycationic amphiphilic cyclodextrin-based nanoparticles [132] and it has been employed for gene delivery of interleukin-12 (IL-12). For siRNA therapeutic delivery, one group of researchers used arginine-engrafted biodegradable polymer as delivery system [133]. This delivery system improved accumulation of carrier-siRNA complexes in the tumour tissue. However, there is vital need for the production

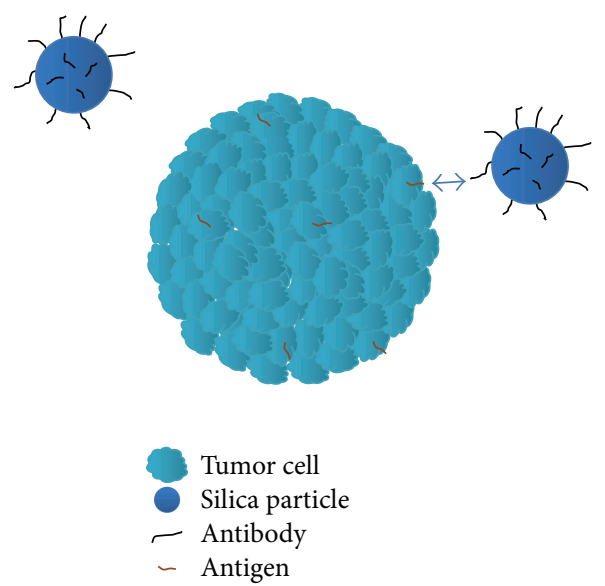

Figure 3: Schematic diagram depicting targeted delivery of antibody labelled silica nanoparticle to the tumour cell antigen.

of a common platform for nanoparticle based delivery systems which can be customized only to deliver different kinds of nucleic acids such as DNA, RNA, and siRNA without any side effect to the patients. 


\section{Future Prospects}

Delivery systems for proteins and genes have taken more than 25 years to emerge as a feasible pharmaceutical tool and several therapeutic proteins and genes are marketed already (Table 1). Liposomes, PEGylation, HESylation, and nanoparticle based delivery are now established as the processes of choice for improving the PK and PD of protein and gene based therapeutic pharmaceuticals. During the development of next generation delivery system some points should be considered, which are as follows: (i) simplicity of the drug and its delivery system: the drug should be easy for manufacturing, quality control, handling and comparatively low-cost. (ii) Safety problems should be minimal. No extra chemical entities should be used which may affect structural stability. (iii) Oral delivery is still a challenge for therapeutic proteins and genes due to their resistance to proteolysis. Further, researches should be more inclined toward this mode of delivery.

\section{Concluding Remarks}

In the age of molecular medicine, a number of protein and gene deliveries have been developed while exploring liposomes, PEGylation, HESylation, and nanoparticle based methods. Past two decades have witnessed the accessibility of commercially available therapeutic products of protein and gene with the different kinds of delivery system. The next generation state-of-the-art gene based and protein based therapies may also improve effectiveness or reduce toxicities. Recent progress in the past two decades, in the field of protein and gene delivery, shows promise and provides bright hopeful future to the patients.

\section{Conflict of Interests}

The authors declare no conflict of interests.

\section{Authors' Contribution}

All authors contributed equally.

\section{Acknowledgments}

This research was supported by a grant of the Korea Health Technology R\&D Project through the Korea Health Industry Development Institute (KHIDI), funded by the Ministry of Health \& Welfare, Republic of Korea (HI12C1265) and by Hallym University Research Fund.

\section{References}

[1] B. Leader, Q. J. Baca, and D. E. Golan, "Protein therapeutics: a summary and pharmacological classification," Nature Reviews Drug Discovery, vol. 7, no. 1, pp. 21-39, 2008.

[2] C. Chakraborty and R. Jhingan, Protein Based Drugs: Techno Commercial Approach, Biotech Books, New Delhi, India, 2005.

[3] F. G. Banting, C. H. Best, J. B. Collip, W. R. Campbell, and A. A. Fletcher, "Pancreatic extracts in the treatment of diabetes mellitus: preliminary report 1922," Canadian Medical Association Journal, vol. 145, no. 10, pp. 1281-1286, 1991.

[4] J. Pickup, "Human insulin," British Medical Journal, vol. 292, no. 6514, pp. 155-157, 1986.

[5] G. Schernthaner, "Immunogenicity and allergenic potential of animal and human insulins," Diabetes Care, vol. 16, no. 3, pp. 155-165, 1993.

[6] D. V. Goeddel, D. G. Kleid, and F. Bolivar, "Expression in Escherichia coli of chemically synthesized genes for human insulin," Proceedings of the National Academy of Sciences of the United States of America, vol. 76, no. 1, pp. 106-110, 1979.

[7] H. Keen, A. Glynne, and J. C. Pickup, "Human insulin produced by recombinant DNA technology: safety and hypoglycaemic potency in healthy men," The Lancet, vol. 2, no. 8191, pp. 398401, 1980.

[8] A. J. L. Clark, R. O. Adeniyi-Jones, G. Knight et al., "Biosynthetic human insulin in the treatment of diabetes," The Lancet, vol. 2, no. 8294, pp. 354-357, 1982.

[9] C. Chakraborty, Production Technology of Recombinant Therapeutic Proteins, Biotech Books, New Delhi, India, 2004.

[10] G. Walsh, "Biopharmaceutical benchmarks 2010," Nature Biotechnology, vol. 28, no. 9, pp. 917-924, 2010.

[11] C. Chakraborty and G. Agoramoorthy, "A special report on India's biotech scenario: advancement in biopharmaceutical and health care sectors," Biotechnology Advances, vol. 28, no. 1, pp. 1-6, 2010.

[12] T. Friedmann and R. Roblin, "Gene therapy for human genetic disease?” Science, vol. 175, no. 4025, pp. 949-955, 1972.

[13] M. L. Edelstein, M. R. Abedi, and J. Wixon, "Gene therapy clinical trials worldwide to 2007-an update," Journal of Gene Medicine, vol. 9, no. 10, pp. 833-842, 2007.

[14] S. L. Ginn, I. E. Alexander, M. L. Edelstein, M. R. Abedi, and J. Wixon, "Gene therapy clinical trials worldwide to 2012-an update," Journal of Gene Medicine, vol. 15, no. 2, pp. 65-77, 2013.

[15] O. Kayser and H. Warzecha, Eds., Pharmaceutical Biotechnology: Drug Discovery and Clinical Applications, John Wiley \& Sons, 2012.

[16] T. M. Allen and P. R. Cullis, "Drug delivery systems: entering the mainstream," Science, vol. 303, no. 5665, pp. 1818-1822, 2004.

[17] C. Chakraborty, S. Pal, G. P. Doss, Z. Wen, and C. Lin, "Nanoparticles as "smart" pharmaceutical delivery," Frontiers in Bioscience, vol. 18, no. 3, pp. 1030-1050, 2013.

[18] K. Fletcher, "Drug delivery: strategies and technologies," Pharmaceutical Science \& Technology Today, vol. 1, no. 2, pp. 49-51, 1998.

[19] A. T. Florence, "New drug delivery systems," Chemistry and Industry, no. 24, pp. 1000-1004, 1993.

[20] R. Langer, "New methods of drug delivery," Science, vol. 249, no. 4976, pp. 1527-1533, 1990.

[21] R. K. Verma and S. Garg, "Current status of drug delivery technologies and future directions," Pharmaceutical Technology, vol. 25, no. 2, pp. 1-14, 2001.

[22] L. R. Brown, "Commercial challenges of protein drug delivery," Expert Opinion on Drug Delivery, vol. 2, no. 1, pp. 29-42, 2005.

[23] J. M. Reichert, "Trends in development and approval times for new therapeutics in the United States," Nature Reviews Drug Discovery, vol. 2, no. 9, pp. 695-702, 2003.

[24] Y. Seow and M. J. Wood, "Biological gene delivery vehicles: beyond viral vectors," Molecular Therapy, vol. 17, no. 5, pp. 767777, 2009. 
[25] D. S. Dimitrov, “Therapeutic proteins," Methods in Molecular Biology, vol. 899, pp. 1-26, 2012.

[26] D. S. Pisal, M. P. Kosloski, and S. V. Balu-Iyer, "Delivery of therapeutic proteins," Journal of Pharmaceutical Sciences, vol. 99, no. 6, pp. 2557-2575, 2010.

[27] M. A. Kay, "State-of-the-art gene-based therapies: the road ahead," Nature Reviews Genetics, vol. 12, no. 5, pp. 316-328, 2011.

[28] D. B. Kohn, "Update on gene therapy for immunodeficiencies," Clinical Immunology, vol. 135, no. 2, pp. 247-254, 2010.

[29] F. Depreter, G. Pilcer, and K. Amighi, "Inhaled proteins: challenges and perspectives," International Journal of Pharmaceutics, vol. 447, no. 1-2, pp. 251-280, 2013.

[30] P. Zhang, K. F. Chan, R. Haryadi, M. Bardor, and Z. Song, "CHO glycosylation mutants as potential host cells to produce therapeutic proteins with enhanced efficacy," Advances in Biochemical Engineering/Biotechnology, vol. 131, pp. 63-87, 2013.

[31] G. Gregoriadis, S. Jain, I. Papaioannou, and ETAL, "Improving the therapeutic efficacy of peptides and proteins: a role for polysialic acids," International Journal of Pharmaceutics, vol. 300, no. 1-2, pp. 125-130, 2005.

[32] U. V. Banakar, "Advances and opportunities in delivery of therapeutic proteins and peptides," Journal of Biomaterials Applications, vol. 11, no. 4, pp. 377-429, 1997.

[33] Y. Levy, M. S. Hershfield, C. Fernandez-Mejia et al., "Adenosine deaminase deficiency with late onset of recurrent infections: response to treatment with polyethylene glycol-modified adenosine deaminase," Journal of Pediatrics, vol. 113, no. 2, pp. 312-317, 1988.

[34] S. Coura Rdos and N. B. Nardi, "The state of the art of adenoassociated virus based vectors in gene therapy," Virology Journal, vol. 7, article 12, 2007.

[35] S. Hacein-Bey-Abina, A. Garrigue, G. P. Wang et al., "Insertional oncogenesis in 4 patients after retrovirus-mediated gene therapy of SCID-X1," Journal of Clinical Investigation, vol. 118, no. 9, pp. 3132-3142, 2008.

[36] B. Kedika and S. V. Patri, "Benzothiazole head group based cationic lipids: synthesis and application for gene delivery," European Journal of Medicinal Chemistry, vol. 74, pp. 703-716, 2013.

[37] J. Sánchez-Nieves, P. Fransen, D. Pulido et al., "Amphiphilic cationic carbosilane-PEG dendrimers: synthesis and applications in gene therapy," European Journal of Medicinal Chemistry, vol. 76, pp. 43-52, 2014.

[38] J. Swaminathan and C. Ehrhardt, "Liposomal delivery of proteins and peptides," Expert Opinion on Drug Delivery, vol. 9, no. 12, pp. 1489-1503, 2012.

[39] H. M. Patel and B. E. Ryman, "Oral administration of insulin by encapsulation within liposomes," The FEBS Letters, vol. 62, no. 1, pp. 60-63, 1976.

[40] H. M. Patel, R. W. Stevenson, J. A. Parsons, and B. E. Ryman, "Use of liposomes to aid intestinal absorption of entrapped insulin in normal and diabetic dogs," Biochimica et Biophysica Acta, vol. 716, no. 2, pp. 188-193, 1982.

[41] C. Chiang and N. Weiner, "Gastrointestinal uptake of liposomes. II. In vivo studies," International Journal of Pharmaceutics, vol. 40, no. 1-2, pp. 143-150, 1987.

[42] A. D. Bangham, M. M. Standish, and J. C. Watkins, "Diffusion of univalent ions across the lamellae of swollen phospholipids," Journal of Molecular Biology, vol. 13, no. 1, pp. 238-252, 1965.

[43] L. D. Mayer, P. R. Cullis, and M. B. Bally, "The use of transmembrane $\mathrm{pH}$ gradient-driven drug encapsulation in the pharmacodynamic evaluation of liposomal doxorubicin," Journal of Liposome Research, vol. 4, no. 1, pp. 529-553, 1994.

[44] D. D. Lasic, "Recent developments in medical applications of liposomes: sterically stabilized liposomes in cancer therapy and gene delivery in vivo," Journal of Controlled Release, vol. 48, no. 2-3, pp. 203-222, 1997.

[45] A. S. Ulrich, "Biophysical aspects of using liposomes as delivery vehicles," Bioscience Reports, vol. 22, no. 2, pp. 129-150, 2002.

[46] G. Gregoriadis, Liposomes as Drug Carriers. Recent Trend and Progress, John Wiley \& Sons, New York, NY, USA, 1988.

[47] M. L. Immordino, F. Dosio, and L. Cattel, "Stealth liposomes: review of the basic science, rationale, and clinical applications, existing and potential," International Journal of Nanomedicine, vol. 1, no. 3, pp. 297-315, 2006.

[48] R. M. Abra, R. B. Bankert, F. Chen et al., "The next generation of liposome delivery systems: recent experience with tumortargeted, sterically-stabilized immunoliposomes and activeloading gradients," Journal of Liposome Research, vol. 12, no. 1-2, pp. 1-3, 2002.

[49] L. Cattel, M. Ceruti, and F. Dosio, "From conventional to stealth liposomes: a new frontier in cancer chemotherapy," Journal of Chemotherapy, vol. 16, no. 4, pp. 94-97, 2004.

[50] P. A. Dinndorf, J. Gootenberg, M. H. Cohen, P. Keegan, and R. Pazdur, "FDA drug approval summary: pegaspargase (Oncaspar) for the first-line treatment of children with acute lymphoblastic leukemia (ALL)," Oncologist, vol. 12, no. 8, pp. 991-998, 2007.

[51] R. M. Bukowski, C. Tendler, D. Cutler, E. Rose, M. M. Laughlin, and P. Statkevich, "Treating cancer with PEG intron: pharmacokinetic profile and dosing guidelines for an improved interferon-alpha-2b formulation," Cancer, vol. 95, no. 2, pp. 389-396, 2002.

[52] M. W. Fried, M. L. Shiffman, R. K. Reddy et al., "Pegylated $(40 \mathrm{kDa})$ interferon alfa-2a (in combination with ribavirin: efficacy and safety results from a phase III, randomized, activelycontrolled, multicenter study," Gastroenterology, vol. 120, no. 5, article A55, 2001.

[53] G. Molineux, "The design and development of pegfilgrastim (PEG-rmetHuG-CSF, Neulasta)," Current Pharmaceutical Design, vol. 10, no. 11, pp. 1235-1244, 2004.

[54] I. C. Macdougall and K. U. Eckardt, "Novel strategies for stimulating erythropoiesis and potential new treatments for anaemia," The Lancet, vol. 368, no. 9539, pp. 947-953, 2006.

[55] D. Haussecker, "The business of RNAi therapeutics in 2012," Molecular Therapy-Nucleic Acids, vol. 7, no. 1, article e8, 2012.

[56] H. Büning, "Gene therapy enters the pharma market: the short story of a long journey," EMBO Molecular Medicine, vol. 5, no. 1, pp. 1-3, 2013.

[57] O. G. Mouritsen and K. Jørgensen, "A new look at lipidmembrane structure in relation to drug research," Pharmaceutical Research, vol. 15, no. 10, pp. 1507-1519, 1998.

[58] M. Langner and T. E. Kral, "Liposome-based drug delivery systems," Polish Journal of Pharmacology, vol. 51, no. 3, pp. 211222, 1999.

[59] M. Langner, "Effect of liposome molecular composition on its ability to carry drugs," Polish Journal of Pharmacology, vol. 52, no. 1, pp. 3-14, 2000.

[60] D. C. Drummond, M. Zignani, and J. Leroux, "Current status of pH-sensitive liposomes in drug delivery," Progress in Lipid Research, vol. 39, no. 5, pp. 409-460, 2000. 
[61] I. M. Hafez and P. R. Cullis, "Roles of lipid polymorphism in intracellular delivery," Advanced Drug Delivery Reviews, vol. 47, no. 2-3, pp. 139-148, 2001.

[62] R. New, Liposomes-A Practical Approach, vol. 58, IRL Press at Oxford University Press, 1994.

[63] R. B. Gennis, Biomembranes: Molecular Structure and Function, Springer, 1989, edited by C. Cantor.

[64] K. Ramani, R. D. Miclea, V. S. Purohit, D. E. Mager, R. M. Straubinger, and S. V. Balu-Iyer, "Phosphatidylserine containing liposomes reduce immunogenicity of recombinant human factor VIII (rFVIII) in a murine model of hemophilia A," Journal of Pharmaceutical Sciences, vol. 97, no. 4, pp. 1386-1398, 2008.

[65] D. C. Drummond, O. Meyer, K. Hong, D. B. Kirpotin, and D. Papahadjopoulos, "Optimizing liposomes for delivery of chemotherapeutic agents to solid tumors," Pharmacological Reviews, vol. 51, no. 4, pp. 691-744, 1999.

[66] V. P. Torchilin and V. S. Trubetskoy, "Which polymers can make nanoparticulate drug carriers long-circulating?" Advanced Drug Delivery Reviews, vol. 16, no. 2-3, pp. 141-155, 1995.

[67] H. Maeda, T. Sawa, and T. Konno, "Mechanism of tumortargeted delivery of macromolecular drugs, including the EPR effect in solid tumor and clinical overview of the prototype polymeric drug SMANCS," Journal of Controlled Release, vol. 74, no. 1-3, pp. 47-61, 2001.

[68] E. Mastrobattista, G. A. Koning, L. Van Bloois, A. C. S. Filipe, W. Jiskoot, and G. Storm, "Functional characterization of an endosome-disruptive peptide and its application in cytosolic delivery of immunoliposome-entrapped proteins," Journal of Biological Chemistry, vol. 277, no. 30, pp. 27135-27143, 2002.

[69] G. Bendas, A. Krause, R. Schmidt, and J. Vogel, "Selectins as new targets for immunoliposome-mediated drug delivery: a potential way of anti-inflammatory therapy," Pharmaceutica Acta Helvetiae, vol. 73, no. 1, pp. 19-26, 1998.

[70] S. M. Moghimi and J. Szebeni, "Stealth liposomes and long circulating nanoparticles: critical issues in pharmacokinetics, opsonization and protein-binding properties," Progress in Lipid Research, vol. 42, no. 6, pp. 463-478, 2003.

[71] K. Maruyama, T. Takizawa, N. Takahashi, T. Tagawa, K. Nagaike, and M. Iwatsuru, "Targeting efficiency of PEGimmunoliposome-conjugated antibodies at PEG terminals," Advanced Drug Delivery Reviews, vol. 24, no. 2-3, pp. 235-242, 1997.

[72] V. P. Torchilin, "Recent advances with liposomes as pharmaceutical carriers," Nature Reviews Drug Discovery, vol. 4, no. 2, pp. 145-160, 2005.

[73] A. A. Gabizon, "Liposome circulation time and tumor targeting: implications for cancer chemotherapy," Advanced Drug Delivery Reviews, vol. 16, no. 2-3, pp. 285-294, 1995.

[74] I. Matsuda, H. Konno, T. Tanaka, and S. Nakamura, "Antimetastatic effect of hepatotropic liposomal adriamycin on human metastatic liver tumors," Surgery Today, vol. 31, no. 5, pp. 414-420, 2001.

[75] M. Hashida, M. Nishikawa, F. Yamashita, and Y. Takakura, "Cell-specific delivery of genes with glycosylated carriers," Advanced Drug Delivery Reviews, vol. 52, no. 3, pp. 187-196, 2001.

[76] J. H. Felgner, R. Kumar, C. N. Sridhar et al., "Enhanced gene delivery and mechanism studies with a novel series of cationic lipid formulations," Journal of Biological Chemistry, vol. 269, no. 4, pp. 2550-2561, 1994.
[77] H. Farhood, N. Serbina, and L. Huang, "The role of dioleoyl phosphatidylethanolamine in cationic liposome mediated gene transfer," Biochimica et Biophysica Acta: Biomembranes, vol. 1235, no. 2, pp. 289-295, 1995.

[78] D. B. Stanimirovic, M. Markovic, D. V. Micic, M. Spatz, and B. B. Mrsulja, "Liposome-entrapped superoxide dismutase reduces ischemia/reperfusion 'oxidative stress' in gerbil brain," Neurochemical Research, vol. 19, no. 12, pp. 1473-1478, 1994.

[79] M. E. M. Cruz, M. M. Gaspar, M. B. F. Martins, and M. L. Corvo, "Liposomal superoxide dismutases and their use in the treatment of experimental arthritis," Methods in Enzymology, vol. 391, pp. 395-413, 2005.

[80] Y. Lo, J. Tsai, and J. Kuo, "Liposomes and disaccharides as carriers in spray-dried powder formulations of superoxide dismutase," Journal of Controlled Release, vol. 94, no. 2-3, pp. 259-272, 2004.

[81] V. P. Torchilin, Immobilized Enzymes in Medicine, Springer, Berlin, Germany, 1991.

[82] M. M. Gaspar, R. Perez-Soler, and M. E. M. Cruz, "Biological characterization of L-asparginase liposomal formulations," Cancer Chemotherapy \& Pharmacology, vol. 38, no. 4, pp. 373377, 1996.

[83] J. L. M. Heeremans, R. Prevost, M. E. A. Bekkers et al., "Thrombolytic treatment with tissue-type plasminogen activator ( $t-P A)$ containing liposomes in rabbits: a comparison with free t-PA," Thrombosis and Haemostasis, vol. 73, no. 3, pp. 488-494, 1995.

[84] M. H. Vingerhoeds, H. J. Haisma, S. O. Belliot, R. H. P. Smit, D. J. A. Crommelin, and G. Storm, "Immunoliposomes as enzyme-carriers (immuno-enzymosomes) for antibodydirected enzyme prodrug therapy (ADEPT): optimization of prodrug activating capacity," Pharmaceutical Research, vol. 13, no. 4, pp. 604-610, 1996.

[85] M. J. Fonseca, J. C. Jagtenberg, H. J. Haisma, and G. Storm, "Liposome-mediated targeting of enzymes to cancer cells for site-specific activation of prodrugs: Comparison with the corresponding antibody-enzyme conjugate," Pharmaceutical Research, vol. 20, no. 3, pp. 423-428, 2003.

[86] K. W. C. Mok and P. R. Cullis, "Structural and fusogenic properties of cationic liposomes in the presence of plasmid DNA," Biophysical Journal, vol. 73, no. 5, pp. 2534-2545, 1997.

[87] A. Hirko, F. Tang, and J. A. Hughes, "Cationic lipid vectors for plasmid DNA delivery," Current Medicinal Chemistry, vol. 10, no. 14, pp. 1185-1193, 2003.

[88] B. Martin, M. Sainlos, A. Aissaoui et al., "The design of cationic lipids for gene delivery," Current Pharmaceutical Design, vol. 11, no. 3, pp. 375-394, 2005.

[89] K. Lappalainen, I. Jääskeläinen, K. Syrjänen et al., “Comparison of cell proliferation and toxicity assays using two cationic liposomes," Pharmaceutical Research, vol. 11, no. 8, pp. 1127-1131, 1994.

[90] M. C. Filion and N. C. Phillips, "Toxicity and immunomodulatory activity of liposomal vectors formulated with cationic lipids toward immune effector cells," Biochimica et Biophysica Acta: Biomembranes, vol. 1329, no. 2, pp. 345-356, 1997.

[91] P. L. Felgner, T. R. Gadek, M. Holm et al., "Lipofection: a highly efficient, lipid-mediated DNA-transfection procedure," Proceedings of the National Academy of Sciences of the United States of America, vol. 84, no. 21, pp. 7413-7417, 1987.

[92] D. C. Litzinger, J. M. Brown, I. Wala et al., "Fate of cationic liposomes and their complex with oligonucleotide in vivo," Biochimica et Biophysica Acta-Biomembranes, vol. 1281, no. 2, pp. 139-149, 1996. 
[93] D. D. Stuart and T. M. Allen, "A new liposomal formulation for antisense oligodeoxynucleotides with small size, high incorporation efficiency and good stability," Biochimica et Biophysica Acta-Biomembranes, vol. 1463, no. 2, pp. 219-229, 2000.

[94] N. Maurer, A. Mori, L. Palmer et al., "Lipid-based systems for the intracellular delivery of genetic drugs," Molecular Membrane Biology, vol. 16, no. 1, pp. 129-140, 1999.

[95] S. C. Semple, S. K. Klimuk, T. O. Harasym et al., "Efficient encapsulation of antisense oligonucleotides in lipid vesicles using ionizable aminolipids: formation of novel small multilamellar vesicle structures," Biochimica et Biophysica Acta: Biomembranes, vol. 1510, no. 1-2, pp. 152-166, 2001.

[96] N. Maurer, K. F. Wong, H. Stark et al., "Spontaneous entrapment of polynucleotides upon electrostatic interaction with ethanoldestabilized cationic liposomes," Biophysical Journal, vol. 80, no. 5, pp. 2310-2326, 2001.

[97] S. C. Semple, A. Akinc, J. Chen et al., "Rational design of cationic lipids for siRNA delivery," Nature Biotechnology, vol. 28, no. 2, pp. 172-176, 2010.

[98] D. D. Stuart, G. Y. Kao, and T. M. Allen, "A novel, longcirculating, and functional liposomal formulation of antisense oligodeoxynucleotides targeted against MDR1," Cancer Gene Therapy, vol. 7, no. 3, pp. 466-475, 2000.

[99] A. Akinc, W. Querbes, S. De et al., "Targeted delivery of RNAi therapeutics with endogenous and exogenous ligandbased mechanisms," Molecular Therapy, vol. 18, no. 7, pp. 13571364, 2010.

[100] G. Basha, T. I. Novobrantseva, N. Rosin et al., "Influence of cationic lipid composition on gene silencing properties of lipid nanoparticle formulations of siRNA in antigen-presenting cells," Molecular Therapy, vol. 19, no. 12, pp. 2186-2200, 2011.

[101] M. Jayaraman, S. M. Ansell, B. L. Mui et al., "Maximizing the potency of siRNA lipid nanoparticles for hepatic gene silencing in vivo," Angewandte Chemie-International Edition, vol. 51, no. 34, pp. 8529-8533, 2012.

[102] J. Milton Harris and R. B. Chess, "Effect of pegylation on pharmaceuticals," Nature Reviews Drug Discovery, vol. 2, no. 3, pp. 214-221, 2003.

[103] G. Pasut and F. M. Veronese, "State of the art in PEGylation: the great versatility achieved after forty years of research," Journal of Controlled Release, vol. 161, no. 2, pp. 461-472, 2012.

[104] S. Jevševar, M. Kunstelj, and V. G. Porekar, "PEGylation of therapeutic proteins," Biotechnology Journal, vol. 5, no. 1, pp. 113-128, 2010.

[105] J. González-Valdez, M. Rito-Palomares, and J. Benavides, "Advances and trends in the design, analysis, and characterization of polymer-protein conjugates for "pEGylaided" bioprocesses," Analytical and Bioanalytical Chemistry, vol. 403, no. 8, pp. 2225-2235, 2012.

[106] M. S. Hershfield, "PEG-ADA replacement therapy for adenosine deaminase deficiency: an update alter 8.5 years," Clinical Immunology and Immunopathology, vol. 76, no. 3, part 2, pp. S228-S232, 1995.

[107] K. L. Lindsay, C. Trepo, T. Heintges et al., "A randomized, double-blind trial comparing pegylated interferon alfa- $2 \mathrm{~b}$ to interferon alfa- $2 \mathrm{~b}$ as initial treatment for chronic hepatitis C," Hepatology, vol. 34, no. 2, pp. 395-403, 2001.

[108] Y. Yamamoto, Y. Tsutsumi, Y. Yoshioka et al., "Site-specific pegylation of a lysine-deficient TNF- $\alpha$ with full bioactivity," Nature Biotechnology, vol. 21, no. 5, pp. 546-552, 2003.
[109] R. M. Blaese, K. W. Culver, A. D. Miller et al., "T lymphocytedirected gene therapy for ADA- SCID: initial trial results after 4 years," Science, vol. 270, no. 5235, pp. 475-480, 1995.

[110] S. J. Howe, M. R. Mansour, K. Schwarzwaelder et al., "Insertional mutagenesis combined with acquired somatic mutations causes leukemogenesis following gene therapy of SCID-X1 patients," Journal of Clinical Investigation, vol. 118, no. 9, pp. 3143-3150, 2008.

[111] F. Ferrua, I. Brigida, and A. Aiuti, "Update on gene therapy for adenosine deaminase-deficient severe combined immunodeficiency," Current Opinion in Allergy and Clinical Immunology, vol. 10, no. 6, pp. 551-556, 2010.

[112] H. B. Gaspar, A. Aiuti, F. Porta, F. Candotti, M. S. Hershfield, and L. D. Notarangelo, "How I treat ADA deficiency," Blood, vol. 114, no. 17, pp. 3524-3532, 2009.

[113] A. Aiuti, F. Cattaneo, S. Galimberti et al., "Gene therapy for immunodeficiency due to adenosine deaminase deficiency," The New England Journal of Medicine, vol. 360, no. 5, pp. 447-458, 2009.

[114] S. Ogino, M. L. Gulley, J. T. den Dunnen et al., "Standard mutation nomeclature in molecular diagnostics: practical and educational challenges," Journal of Molecular Diagnostics, vol. 9, no. 1, pp. 1-6, 2007.

[115] H. B. Gaspar, "Bone marrow transplantation and alternatives for adenosine deaminase deficiency," Immunology and Allergy Clinics of North America, vol. 30, no. 2, pp. 221-236, 2010.

[116] H. Schellekens, W. E. Hennink, and V. Brinks, "The immunogenicity of polyethylene glycol: facts and fiction," Pharmaceutical Research, vol. 30, no. 7, pp. 1729-1734, 2013.

[117] M. Noga, D. Edinger, R. Kläger et al., “The effect of molar mass and degree of hydroxyethylation on the controlled shielding and deshielding of hydroxyethyl starch-coated polyplexes," Biomaterials, vol. 34, no. 10, pp. 2530-2538, 2013.

[118] A. Besheer, G. Hause, J. Kressler, and K. Mäder, "Hydrophobically modified hydroxyethyl starch: synthesis, characterization, and aqueous self-assembly into nano-sized polymeric micelles and vesicles," Biomacromolecules, vol. 8, no. 2, pp. 359-367, 2007.

[119] GMBH FKD, "Hesylation Technology; AAPS National Biotechnology Conference," Toronto, Canada, abstract, 2008.

[120] A. O. Elzoghby, W. M. Samy, and N. A. Elgindy, "Albumin-based nanoparticles as potential controlled release drug delivery systems," Journal of Controlled Release, vol. 157, no. 2, pp. 168182, 2012.

[121] E. J. Lee, S. A. Khan, J. K. Park, and K. Lim, "Studies on the characteristics of drug-loaded gelatin nanoparticles prepared by nanoprecipitation," Bioprocess and Biosystems Engineering, vol. 35, no. 1-2, pp. 297-307, 2012.

[122] T. Mirshahi, J. M. Irache, C. Nicolas et al., "Adaptive immune responses of legumin nanoparticles," Journal of Drug Targeting, vol. 10, no. 8, pp. 625-631, 2002.

[123] L. Vincent, J. Varet, J. Pille et al., "Efficacy of dendrimermediated angiostatin and TIMP-2 gene delivery on inhibition of tumor growth and angiogenesis: In vitro and in vivo studies," International Journal of Cancer, vol. 105, no. 3, pp. 419-429, 2003.

[124] C. H. Ahn, S. Y. Chae, Y. H. Bae, and S. W. Kim, "Biodegradable poly(ethylenimine) for plasmid DNA delivery," Journal of Controlled Release, vol. 80, no. 1-3, pp. 273-282, 2002.

[125] G. F. Paciotti, L. Myer, D. Weinreich et al., "Colloidal gold: a novel nanoparticle vector for tumor directed drug delivery," Drug Delivery, vol. 11, no. 3, pp. 169-183, 2004. 
[126] G. Kaul and M. Amiji, “Tumor-targeted gene delivery using poly(ethylene glycol)-modified gelatin nanoparticles: in vitro and in Vivo studies," Pharmaceutical Research, vol. 22, no. 6, pp. 951-961, 2005.

[127] W. Tan, K. Wang, X. He et al., "Bionanotechnology based on silica nanoparticles," Medicinal Research Reviews, vol. 24, no. 5, pp. 621-638, 2004.

[128] C. Kneuer, M. Sameti, U. Bakowsky et al., "A nonviral DNA delivery system based on surface modified silica-nanoparticles can efficiently transfect cells in vitro," Bioconjugate Chemistry, vol. 11, no. 6, pp. 926-932, 2000.

[129] C. Kneuer, M. Sameti, E. G. Haltner et al., "Silica nanoparticles modified with aminosilanes as carriers for plasmid DNA," International Journal of Pharmaceutics, vol. 196, no. 2, pp. 257261, 2000.

[130] N. Singh, M. Briones, G. Ott, and D. O’Hagan, "Cationic microparticles: a potent delivery system for DNA vaccines," Proceedings of the National Academy of Sciences of the United States of America, vol. 97, no. 2, pp. 811-816, 2000.

[131] M. Junghans, J. Kreuter, and A. Zimmer, "Antisense delivery using protamine-oligonucleotide particles," Nucleic Acids Research, vol. 28, article E45, no. 10, 2000.

[132] A. Méndez-Ardoy, K. Urbiola, C. Aranda, C. Ortiz-Mellet, J. M. Garca-Fernndez, and C. Tros de Ilarduya, "Polycationic amphiphilic cyclodextrin-based nanoparticles for therapeutic gene delivery," Nanomedicine, vol. 6, no. 10, pp. 1697-1707, 2011.

[133] J. Beloor, C. S. Choi, H. Y. Nam et al., "Arginine-engrafted biodegradable polymer for the systemic delivery of therapeutic siRNA," Biomaterials, vol. 33, no. 5, pp. 1640-1650, 2012. 

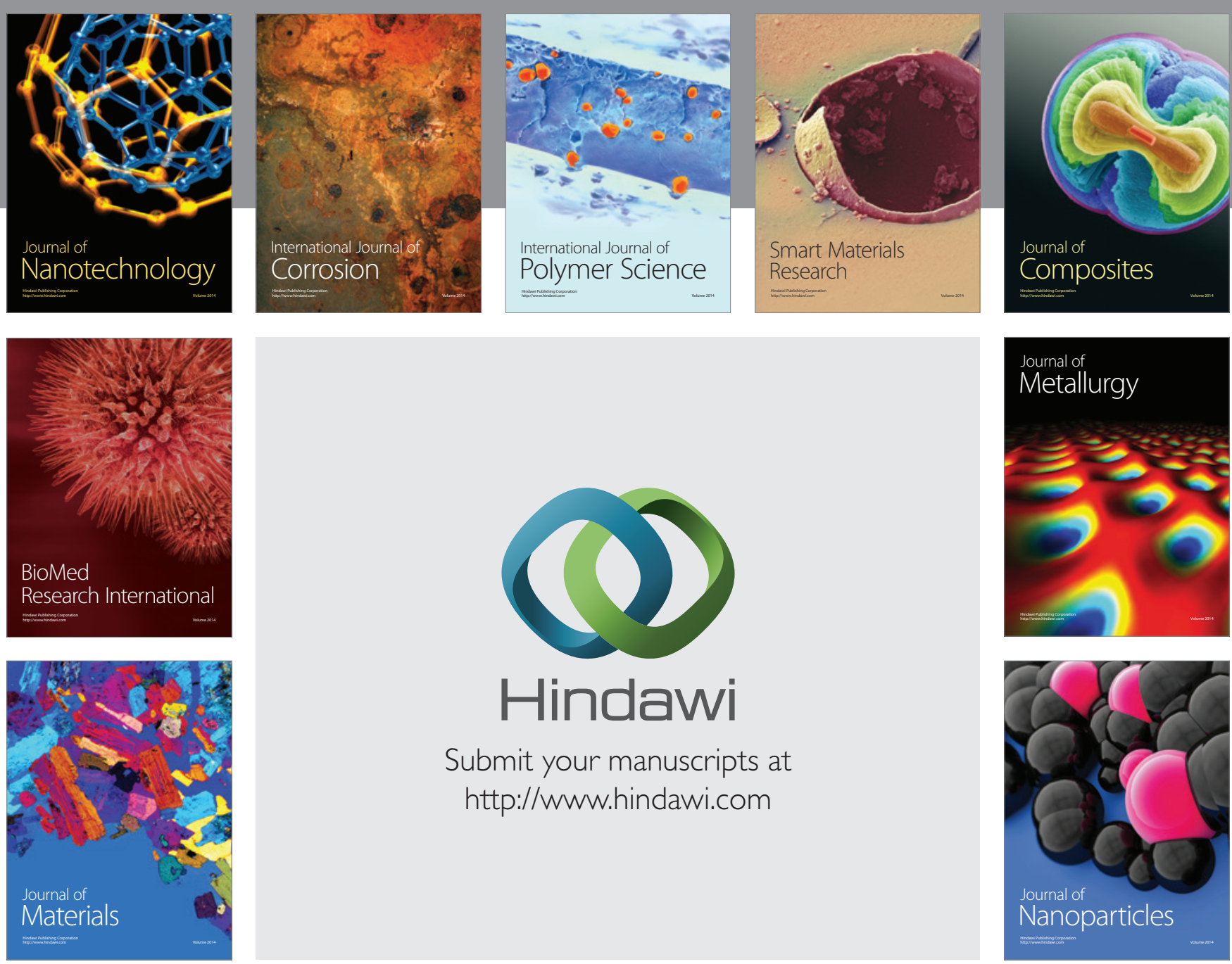

Submit your manuscripts at http://www.hindawi.com
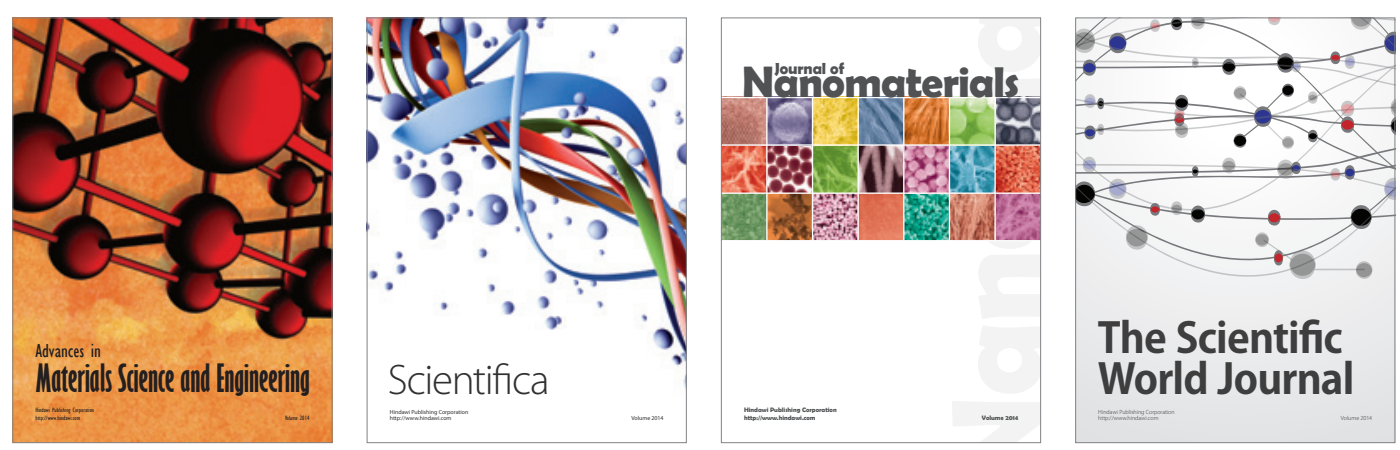

\section{The Scientific World Journal}
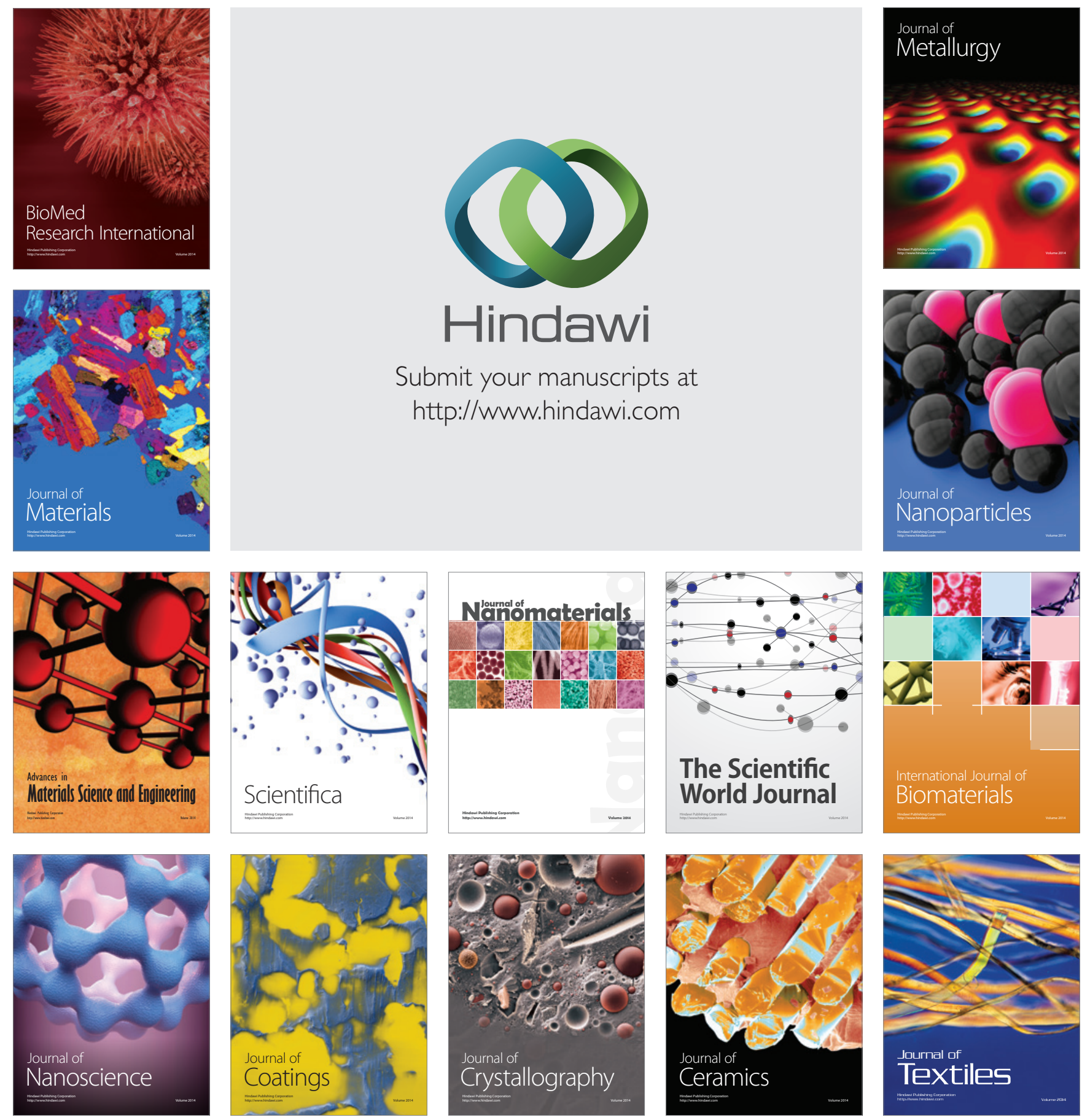